\title{
The Epigenetics of Early Lymphocyte Development
}

\author{
C. MurRe \\ Department of Molecular Biology, University of California, San Diego, La Jolla, California 92093 \\ Correspondence: murre@biomail.ucsd.edu
}

\begin{abstract}
The mammalian genome is highly structured, both spatially and functionally. Chromosomes are organized into specific territories, which are further folded into euchromatic or heterochromatic compartments. The euchromatic compartment often contains domains decorated with activating epigenetic marks, whereas heterochromatic regions lack activating marks or bear repressive ones. During lymphocyte development, gene segments move between these compartments. Additionally, some genes undergoing changes in transcriptional activity also display elaborate alterations in chromatin folding. Lineage-specific transcription factors help mediate these reconfigurations. Herein, I describe how genetic loci encoding for key regulators switch nuclear neighborhoods and reorganize their 3D structures to drive cell fate.
\end{abstract}

Early imaging studies revealed that mammalian chromosomes are organized into topological domains similar as originally described for polytene chromosomes of Drosophila (Paulson and Laemmli 1977; Sedat and Manuelidis 1978). The unit of the chromatin fiber is the nucleosome. Nucleosomes contain an octamer of histones wound with DNA, packaged as a 30 -nm polymer chain. Beyond the $30 \mathrm{~nm}$ fiber, the chromatin fiber is also highly structured to permit encounters between regulatory elements with the appropriate frequencies.

In the past 20 years, several models have been proposed to describe long-range chromatin architecture. Prominent among these models are (1) the random walk/giant loop (RW/GL); (2) the multi-loop-subcompartment (MLS); and (3) the random-loop (RL). The RW/GL model describes random walk behavior constrained by very large loops (2-5 Mbp) (Sachs et al. 1995). The MLS model depicts the genome folded into $\sim 1$-Mbp chromatin domains, consisting of bundles of loops interconnected by linkers (Münkel et al. 1999). The RL model proposes a dynamic genome consisting of small and large loops (Bohn et al. 2007). Using these models as a starting configuration, the simulated spatial distances between chromatin regions have been compared to experimentally measured ones. These analyses predicted that chromatin domains within the immunoglobulin heavy chain (Igh) locus consisted of bundles of loops separated by linkers (Jhunjhunwala et al. 2008; Guo et al. 2011a). Recent chromosome conformation-capture studies of the $\alpha$-globin locus led to analogous conclusions in favor of distinct domains containing clusters of loops (Bau et al. 2011). Similarly, genome-wide studies in vertebrate organisms validated these findings, supporting topological domains containing clusters of loops (Fullwood et al. 2009; Lieberman-Aiden et al. 2009; Dixon et al. 2012; Lin et al. 2012; Sexton et al. 2012). Such domains were closely associated with the deposition of epigenetic marks characteristic of transcriptionally active regions (Fullwood et al. 2009; Lie-
berman-Aiden et al. 2009; Dixon et al. 2012; Sexton et al. 2012). Thus, a picture is now emerging in which the eukaryotic genome, closely resembling the polytene chromosome in Drosophila to self-organize into topological domains, like beads-on-a string.

\section{EARLY HEMATOPOIESIS}

The immune system contains progenitor populations that initiate expression of lineage-specific transcription factors while losing the capacity to adopt alternative cell fates (Fig. 1). Initially, long-term hematopoietic stem cells (LT-HSCs) generate all immune cells (Weissman 2000). LT-HSCs retain multipotency, self-renewal, and the ability to generate multipotent progenitors (MPPs) (Spangrude et al. 1998). MPPs are distinct from HSCs as they reconstitute the full hematopoietic compartment but do not self-renew. Rather, MPPs may develop into erythrocytes or megakaryocytes or, alternatively, differentiate into lymphoid-primed MPPs (LMPPs) (Adolfsson et al. 2005). Then, LMPPs readily differentiate into granulocyte-macrophage progenitors (GMPs) or, alternatively, common lymphoid progenitors (CLPs) (Kondo et al. 1997; Wada et al. 2008). In turn, GMPs give rise to macrophages or granulocytes, whereas CLPs differentiate into the plasmacytoid dendritic, NK-, B-, or T-cell lineages (Lai and Kondo 2006; Pronk et al. 2007). The stable identity of each compartment relies on properly titrated expression of transcription factors. External cues, such as cytokine and receptor-mediated signals, also determine cell fate.

Signals from the macrophage colony stimulating factor receptor (MCSF-R) or granulocyte-CSFR (GCSF-R) upon exposure of G-CSF, M-CSF, and/or GM-CSF, respectively, help direct myeloid differentiation toward the neutrophil or macrophage lineages (Cecchini et al. 1994). The relative dosage of PU.1 versus $\mathrm{C} / \mathrm{EBP} \alpha$ controls the neutrophil/macrophage lineage decision, with high PU.1 


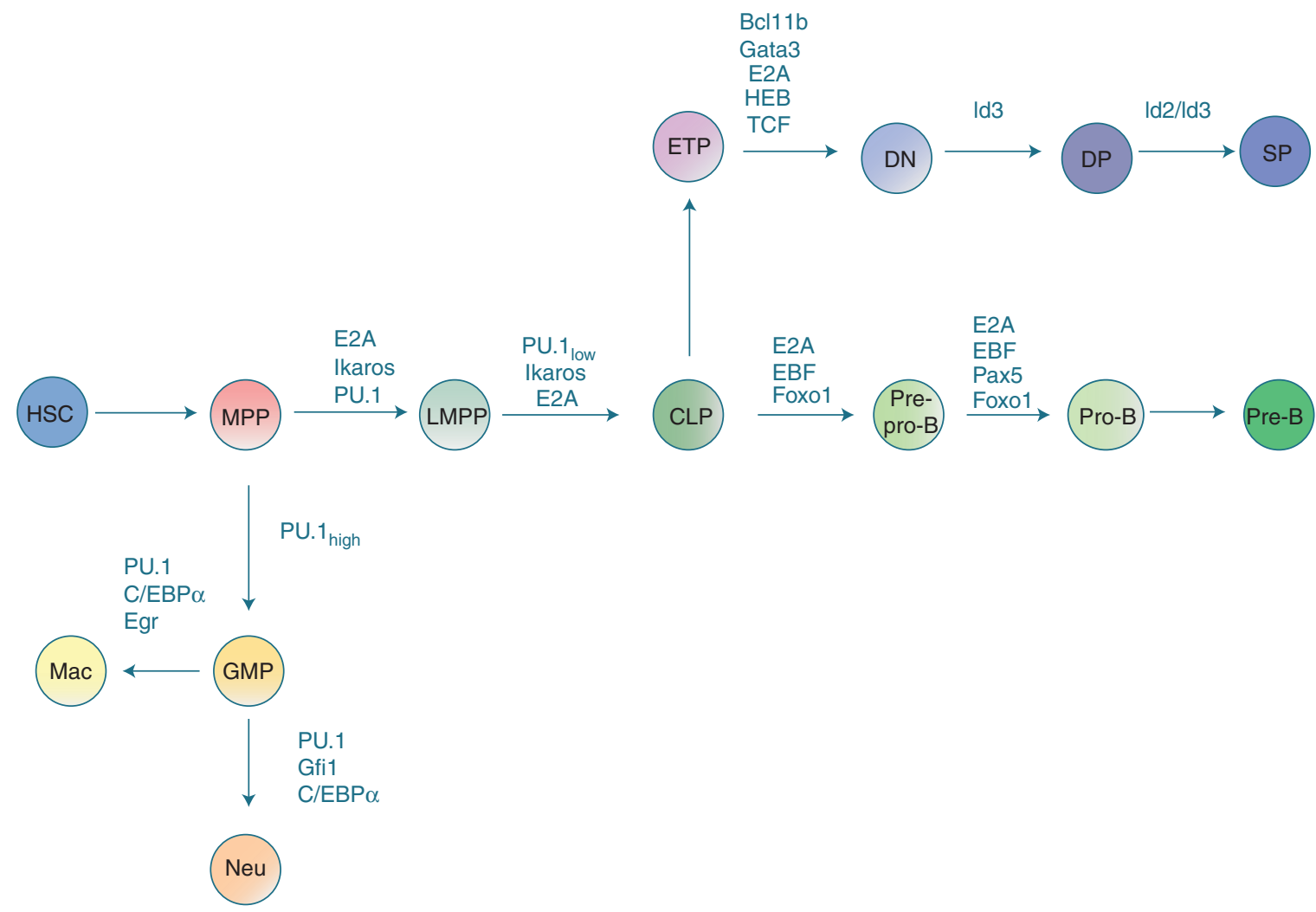

Figure 1. Transcriptional control of early hematopoiesis. HSC, hematopoietic stem cell compartment; MPP, multipotent progenitor cell stage; LMPP, lymphoid-primed multipotent progenitor compartment; GMP, granulocyte-macrophage progenitor population; CLP, common lymphoid progenitor compartment; Gran, granulocytes; Mac, macrophage compartment; Neu, neutrophils; ETP, early thymocyte progenitor population; DN, thymocyte progenitors that lack CD4 and CD8 expression; DP, immature thymocytes that express both CD4 and CD8; SP, mature thymocytes that express either CD4 or CD8.

favoring macrophage development and high $\mathrm{C} / \mathrm{EBP} \alpha$ favoring neutrophil development (DeKoter and Singh 2000; Laslo et al. 2006).

Antigen-receptor expression distinguishes $\mathrm{B}$ and $\mathrm{T}$ lymphocytes from these GMP-derived innate cells. Among B-cell progenitors, the CLP compartment can be further subdivided into two distinct subsets: Ly6D ${ }^{-}$ and Ly6D ${ }^{+}$(Inlay et al. 2009; Mansson et al. 2010). The Ly6 $\mathrm{D}^{+}$pool gives rise to $\mathrm{B}$ cells through intermediates such as $\mathrm{B} 220^{\text {int }} \mathrm{CD} 43^{\text {high }}$ pre-pro-B cells and $\mathrm{B} 220^{\text {high }} \mathrm{CD} 19^{\text {high }}$ pro-B cells. Igh locus $\mathrm{D}_{\mathrm{H}} \mathrm{J}_{\mathrm{H}}$ joints are already generated in the CLP compartment but $\mathrm{V}_{\mathrm{H}} \mathrm{D}_{\mathrm{H}} \mathrm{J}_{\mathrm{H}}$ rearrangement is not initiated until the $\mathrm{CD} 43^{+}$stage. A productive Igh chain permits pro-B cells to undergo rapid expansion and differentiation into pre-B cells.

In contrast, T cells originate either from the LMPP or are generated from the CLP compartment through an intermediate population called early $\mathrm{T}$-cell progenitors (ETPs) (Bell and Bhandoola 2008). ETPs may generate myeloid, dendritic, natural killer (NK), and T-cell progeny (Wada et al. 2008). Thymocytes can be segregated into four distinct classes: $\mathrm{CD}^{-} \mathrm{CD}^{-}(\mathrm{DN}), \mathrm{CD}^{+} \mathrm{CD}^{+}$ (DP), $\mathrm{CD}^{+} \mathrm{CD}^{-}$(CD4SP), and $\mathrm{CD} 4^{-} \mathrm{CD}^{+}$(CD8SP) (Taghon and Rothenberg 2008). The $\mathrm{CD} 4^{-} \mathrm{CD} 8^{-}$(DN) compartment itself consists of four well-defined developmental stages: the DN1, DN2, DN3, and DN4 subsets
(Schmitt and Zuniga-Pflucker 2002). The DN2 compartment further divides into DN2a and DN2b subsets based on the expression of a zinc-finger containing transcription factor Bcl11b, which initiates a T-lineage specific program (Ikawa et al. 2010; Li et al. 2010a, b). Characterized by the differential expression of CD27, the DN3 compartment contains DN3a and DN3b cells (Taghon et al. 2006). Here, T cells undergo TCR $\beta, \gamma$, or $\delta$ locus rearrangement (Livak et al. 1999). Upon productive TCR $\beta$ V(D)J rearrangement, the pre-TCR complex is assembled, leading to rapid cellular expansion and developmental progression to the DP compartment. There, TCR $\alpha$ rearrangement is initiated. As a result of these rearrangements, the newly formed TCR complex faces death by neglect, negative selection, or positive selection.

\section{TRANSCRIPTIONAL CONTROL OF LYMPHOID DEVELOPMENT}

While additional factors will likely emerge, several key regulators controlling B-cell specification and commitment have been characterized in great detail, including E2A, EBF1, FOXO1, and PAX5 (Bain et al. 1994; Lin and Grosschedl 1994; Zhuang et al. 1994; Nutt et al. 1999; Beck et al. 2009; Murre 2009). Among these is the 


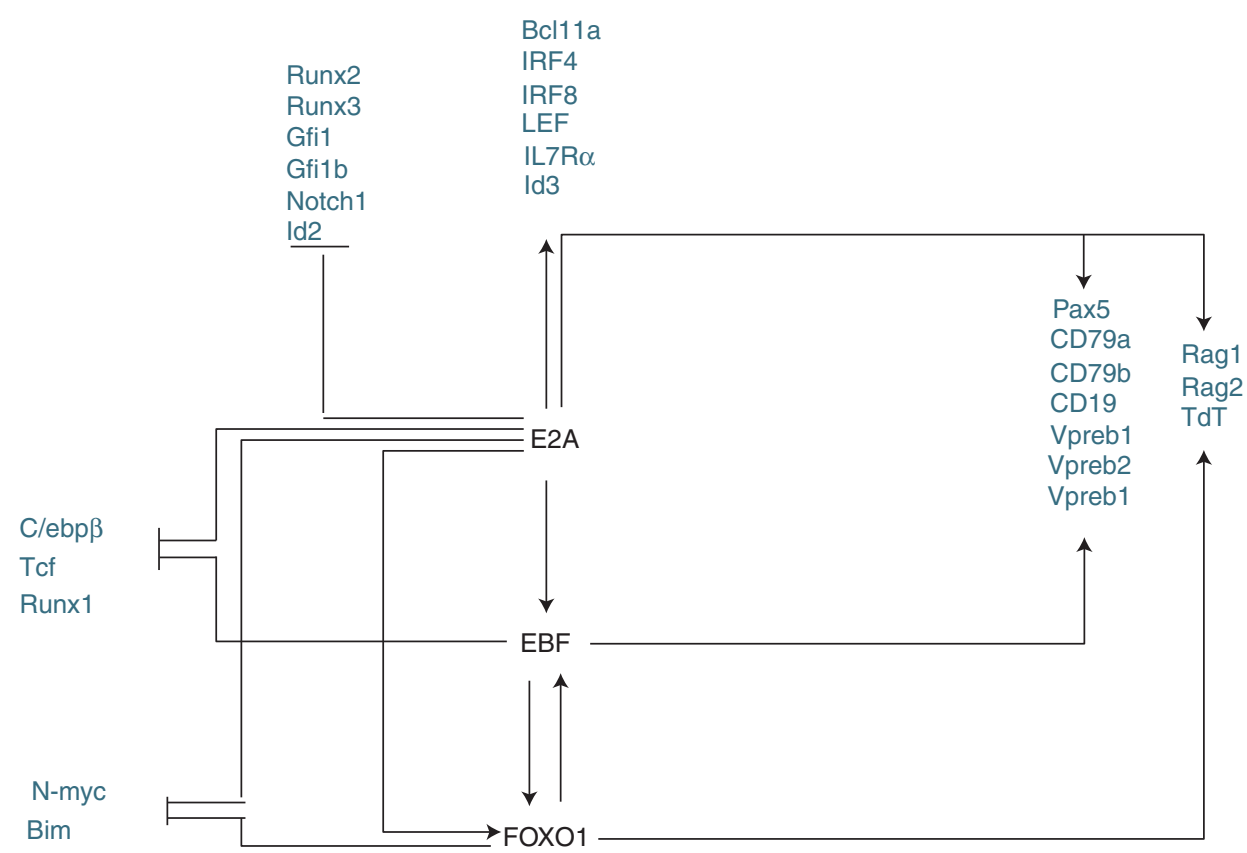

Figure 2. Regulatory network that orchestrates B-cell fate. Transcription factors that promote early B-cell development are indicated. Arrows, positive regulation; bars, transcriptional repression. EBF1 functions as a nodal point. Note that E2A acts to induce the expression of FOXO1. E2A and FOXO1 then act collaboratively to activate EBF1 expression. EBF1 and FOXO1 then act in a positive-feedback circuitry to orchestrate B-cell fate.

E2A gene, which encodes for two proteins, E12 and E47. They arise through differential splicing in exons encoding for the basic helix-loop-helix (bHLH) domain (Murre 2005). In the absence of E2A, B-cell development is completely blocked in the CLP compartment (Inlay et al. 2009). E2A-deficient mice contain Ly6D $^{-}$cells, but lack Ly6D ${ }^{+}$expressers. Typically, the E2A proteins act in concert with HEB, another bHLH protein, to induce the expression of FOXO1 at the Ly6D ${ }^{+}$stage. E2A and FOXO1 act together to activate the expression of yet another key regulator, EBF1. EBF1 and FOXO1 coexpression establishes a positive intergenic feedback circuitry to specify B-cell identity (Mansson et al. 2012). Finally, PAX5 is thought to "lock in" the B-cell fate. A diverse set of inputs, including E2A, EBF1, IRF4, IRF8, and PU.1, regulates Pax5 levels (Nutt et al. 1999; Decker et al. 2009). Finally, Pax5 participates in a regulatory feedback loop with EBF1 to commit progenitor cells to the B-cell fate (Medina et al. 2004) (Fig. 2).

Several of the factors controlling B-cell fate also orchestrate T-lineage development. Among these, E-proteins are noteworthy. T-cell precursors express high levels of E2A and HEB (Bain et al. 1997). Consistent with this pattern, thymocyte development in $\mathrm{E} 2 \mathrm{~A}^{-/-}$ mice is blocked, albeit partially, at the DN1 stage. Similarly, forced expression of mutant HEB arrests thymocyte development at this early stage (Barndt et al. 2000). In normal T-lineage progenitors, E47 activates components of the Notch signaling pathway such as Notch1, Notch3, Hes1, Tle3, and Tle6 (Ikawa et al. 2006). Subsequently, E47 works in synergy with Notch signaling to activate $\mathrm{pT} \alpha$ and Hes1. Likewise, HEB acts throughout thymocyte development (Yui et al. 2010). Notch signaling leads to the induction of Tcf1 and Gata3, factors required for Tcell development (Ting et al. 1996; Weber et al. 2011). Gata3 suppresses T-cell progenitor self-renewal and inhibits a B-lineage specific program of gene expression (García-Ojeda et al. 2013).

Moreover, critical targets of E2A and HEB are TCR $\beta$, TCR $\gamma$, and TCR $\delta$ antigen receptor loci (Agata et al. 2007; Yashiro-Ohtani et al. 2009). With the expression of a preTCR, E47 levels decline to permit development beyond the pre-TCR checkpoint. At the TCR checkpoint, E47 further declines to promote positive selection (Engel et al. 2001). Inhibitor of DNA-binding 3 (Id3), an E-protein antagonist, regulates, at least in part, transit through the pre-TCR and TCR checkpoints (Engel et al. 2001; Lauritsen et al. 2009; Jones and Zhuang 2012). Eliminating Id 3 expression after the pre-TCR checkpoint readily leads to loss of naïve T cells through mechanisms yet to be determined (Miyazaki et al. 2011). E2A and Id3 also regulate $\gamma \delta \mathrm{T}$-cell development, antagonizing the development of Vy1.1V86.3 expressers (Ueda-Hayakawa et al. 2009; Alonzo et al. 2010; Lee et al. 2010; Verykokakis et al. 2010; Miyazaki et al. 2011).

\section{GENOME-WIDE STUDIES OF TRANSCRIPTION FACTOR OCCUPANCY}

Recent genome-wide studies provide new insights into how transcription factors orchestrate myeloid and lymphoid cell fates. For example, in myeloid cells, PU.1 binding predominantly occurred at $\mathrm{AP} 1$ and $\mathrm{C} / \mathrm{EBP} \alpha$ consensus binding sites across putative enhancer regions, 
whereas, in B-cell progenitors, PU.1 occupancy primarily associated with EBF1 and E2A-bound sites (Ghisletti et al. 2010; Heinz et al. 2010; Lin et al. 2010). In other words, the pattern of collaborative DNA binding across the enhancer repertoire correlated well with B-lineage versus myeloid-lineage specific transcription signatures. Similarly, in B-lineage progenitors, E2A-bound sites were significantly enriched for EBF1, FOXO1, and ETS/Ikaros consensus binding sites, while in T-cell progenitors, E2A occupancy was primarily associated with Runx and ETS/ Ikaros consensus binding sites (Lin et al. 2010; Miyazaki et al. 2011). Finally, in B-lineage cells, EBF1 occupancy across putative enhancer regions was primarily associated with ETS/Ikaros, E2A, and Pax5 binding sites while Ikaros occupancy at enhancer elements was primarily enriched for E2A, FOXO1, EBF1, and FOXO1 consensus binding sites (Treiber et al. 2010; Ferreirós-Vidal et al. 2013). At distinct stages of B-cell development, largescale changes can be observed as they relate to transcription factor occupancy. In pre-pro-B cells, E2A-bound enhancers are enriched at sites across putative enhancers that are partially distinct from those observed in pro-B cells (Lin et al. 2010). At these sites, E2A binding is predominantly associated with Runx and Ikaros consensus binding DNA sequences. Likewise, enhancer repertoires associated with global PAX5 occupancy differ significantly between pro-B cells and mature-B cells (RevillaI-Domingo et al. 2012).

To define collaborations among transcription factors in the B lineage, mutant cell lines have been generated and examined to assemble a network of genome-wide E2A, EBF1, and FOXO1 occupancy and transcription factor signatures (Lin et al. 2010). Analysis revealed that E2A proteins bind to regulatory elements across EBF1 and FOXO1 loci. EBF1 binding was also observed at regulatory elements associated with the FOXO1 locus, suggesting that EBF1 and FOXO1 may act in a feedback loop to modulate B-cell development. Indeed, these observations were recently confirmed by analysis of EBF1- and FOXO1-deficient CLPs, indicating that EBF1 and FOXO1 act in a positive feedback circuitry to establish B-cell identity (Mansson et al. 2012). Taken together, these studies show that the E2A and HEB proteins, noted earlier, act in the CLP compartment to induce the expression of FOXO1. Subsequently, E2A and FOXO1 act together to induce EBF1 expression. In turn, EBF1 binds to regulatory elements at FOXO1 enhancers to establish a positive intergenic regulatory feedback loop for B-cell identity. Once EBF1 takes hold, it collaborates with E2A to induce PAX 5 expression.

The global studies also revealed that E2A proteins directly regulated the expression of CCCTC-binding factor (CTCF) (Lin et al. 2010). CTCF functions as an architectural protein to establish nuclear topology. In B-lineage cells, CTCF plays a critical role in modulating the topology of the immunoglobulin loci (Jhunjhunwala et al. 2009; Degner et al. 2011; Guo et al. 2011b). Two distinct subsets of CTCF binding sites were identified. The first subset had CTCF binding sites located between the variable region cluster and the $\mathrm{D}_{\mathrm{H}} \mathrm{J}_{\mathrm{H}}$ elements. These sites acted as insulators, which allowed the onset of $\mathrm{D}_{\mathrm{H}}-\mathrm{J}_{\mathrm{H}}$ recombination to proceed by suppressing $\mathrm{V}_{\mathrm{H}}-\mathrm{D}_{\mathrm{H}}$ rearrangement. The second subset occurred within the proximal $\mathrm{V}_{\mathrm{H}}$ regions. There, CTCF sites were predominantly localized within close genomic proximity of the $\mathrm{V}_{\mathrm{H}}$ gene segments. These sites may help establish a rosette-like topology that sequesters the proximal $\mathrm{V}_{\mathrm{H}}$ region to the base of the rosette surrounding a cavity containing the $\mathrm{D}_{\mathrm{H}} \mathrm{J}_{\mathrm{H}}$ elements (Lucas et al. 2011). Although still to be proven, it seems to be conceivable that the induction of CTCF transcription by the E2A proteins modulates genome topology globally during the developmental transition from the pre-pro-B to the pro-B cell stage.

\section{CHARTING THE TOPOLOGY OF LYMPHOID GENOMES}

It is well appreciated that the eukaryotic genome can be segregated into transcriptionally permissive (euchromatic) and repressive (heterochromatic) compartments (Kind and van Steensel 2010). In the past, although assignment of genes to regions such as nuclear pores, nuclear lamina, or centrally located nuclear domains was possible, this assignment could only be achieved on a gene-by-gene basis. More recently, approaches have been established that permit the assignment of whole genomes to transcriptionally permissive or repressive compartments (Lieberman-Aiden et al. 2009). These strategies identify laminaassociating genomic regions as well as model the folding patterns for the chromatin fiber. These techniques have revealed that, concurrent with the differentiation of embryonic stem cells, a large subset of genes switch nuclear compartments during developmental progression (Kind and van Steensel 2010). Similarly, we have observed large-scale changes in the nuclear environments of genes in pre-pro-B and pro-B cells (Lin et al. 2012). Specifically, in the transition from the pre-pro-B to pro-B-cell stage, a large set of genes $(\sim 250)$ relocated from the heterochromatic to euchromatic compartment, and vice versa (Lin et al. 2012). The repositioning of genes in the nucleus during the pre-pro-B to pro-B-cell transition was closely associated with changes in nascent transcription. Of the genes that showed increased transcript levels in pro-B cells, $251(13 \%)$ were found in regions that switched from the heterochromatic to euchromatic compartment, while $44(2.3 \%)$ of the genes that showed a decrease in expression levels showed the reverse pattern. It is important to note, however, that not the entire spectrum of genes that switched nuclear location displayed changes in active transcription. Rather, a subset of genes that changed nuclear location from the heterochromatic to euchromatic compartment remained transcriptionally silent (Lin et al. 2012). Interestingly, this set of genes was primarily characterized by deposition of $\mathrm{H} 3 \mathrm{~K} 27 \mathrm{me} 3$, an epigenetic mark closely associated with transcriptional silencing. These observations indicate that there are at least two ways of antagonizing gene expression: (1) sequestration to the nuclear lamina, and (2) recruitment to polycomb bodies. Why are these distinct mechanisms of silencing? We envision that being located in polycomb bodies would 
permit silenced genes to rapidly relocate to transcription factories during developmental progression.

Transcriptional inert compartments may serve to completely silence gene expression. On one hand, silenced genes within transcriptionally active neighborhoods risk aberrant activation, for example, by looping of active nearby enhancers to promoter regions. On the other hand, localization within a transcriptionally inert neighborhood mitigates aberrant activation of gene expression since the entire compartment is silenced. Localization to the heterochromatic compartment may be particularly important for those genes encoding for proteins with key regulatory functions.

\section{ANCHORS ACTING AT DIFFERENT LENGTH SCALES}

As described above, the transcriptionally permissive compartment is organized as chromatin globules/domains containing bundles of loops separated by linkers like "beads-on-a-string," as originally proposed by the MLS model (Munkel et al. 1999; Jhunjhunwala et al. 2008). Loop attachment regions within topological chromatin domains are highly enriched for CTCF occupancy (Fullwood et al. 2009; Li et al. 2012). Similarly, lineagespecific transcription factors such as E2A, EBF1, Pax5 and PU.1 are enriched across loop attachment regions (Lin et al. 2012). These factors are also frequently involved, albeit less frequently than CTCF, in mediating genomic interactions between topological domains. There are at least two distinct anchors that weave the genomes of lymphoid cells: (1) anchors that function primarily at the local level (i.e., within chromatin globules) and (2) tethers between factors associated with both intra- and interdomain interactions. How do these two putative anchors differ? The biochemical activities of CTCF and E2A are quite distinct. E2A, PU.1, EBF1, and Pax 5 but not CTCF occupancy is primarily associated with $\mathrm{H} 3 \mathrm{~K} 4 \mathrm{me} 1$ and $\mathrm{H} 3 \mathrm{~K} 4 \mathrm{me} 2$, epigenetic marks of putative enhancers (Lin et al. 2010). Lineage-specific transcription factors, including EBF1, PU.1, and Pax5, are not expressed in the CLP compartment but are activated during the transition from the CLP to the pro-B-cell stage. Thus, lineage-specific transcription factors bind to a vast spectrum of enhancer elements across the pro-B-cell genome to promote genomic interactions not only at enhancers within chromatin domains but also between domains to promote the assembly of transcription factories (Iborra et al. 1996; Cook 1997). It will be important to determine how the entire ensemble of architectural proteins like CTCF and cohesins act in concert with transcriptional regulators such as E2A, EBF1, and FOXO1 to orchestrate the architecture of the pro-B-cell genome and initiate a B-lineage specific program of gene expression.

\section{CONCLUSION}

In early B-cell progenitors, EBF1, FOXO1, Igк, and $\operatorname{Ig} \lambda$ loci but not the Igh locus were among the genes that switched nuclear environments. Studies using 3D-FISH in pre-pro-B cell progenitors largely confirmed these data but also revealed that some EBF1 alleles did not associate with the nuclear lamina (Lin et al. 2012). We suggest that this nonassociated fraction of EBF1 alleles may be silenced by other mechanisms, possibly via deposition of $\mathrm{H} 3 \mathrm{~K} 27 \mathrm{me} 3$, as we have discussed above. Conversely, why silence the EBF1 locus by sequestering it to the nuclear lamina? We suggest that situating active genes within close spatial proximity of EBF1 must be avoided to preclude premature, stochastic activation. At earlier stages of hematopoiesis, factors involved in the induction of EBF1 transcription such as E2A and FOXO1 are expressed at high levels. Again, it is critical to ensure that the EBF1 locus is sequestered away from transcription factories that contain high levels of E2A to prevent aberrant, premature activation of B-lineage genes.

Finally, are other key developmental regulators modulated at the level of nuclear positioning in early hematopoiesis? Interestingly, Bcl11b is also sequestered in the heterochromatic compartment of pre-pro-B cells. Thus, analogous to the EBF1 locus, Bcl11b may be attached to the nuclear lamina to suppress the activation of a T-lineage program. Such a mechanism, it would appear, would not be restricted to hematopoietic progenitors but could be used in all stages of lymphoid and myeloid development. If this was the case, then the positioning of key developmental regulators to the nuclear lamina in progenitor cells would serve as a more general principle to prevent premature activation of lineage-specific programs for gene expression and developmental progression.

\section{ACKNOWLEDGMENTS}

I am grateful to Alex Bortnick for critical reading and editing of the manuscript. Research performed in the Murre laboratory is supported by the National Institutes of Health.

\section{REFERENCES}

Adolfsson J, Månsson R, Buza-Vidas N, Hultquist A, Liuba K, Jensen CT, Bryder D, Yang L, Borge OJ, Thoren LA, et al. 2005. Identification of Flt3 ${ }^{+}$lympho-myeloid stem cells lacking erythro-megakaryocytic potential: A revised road map for adult blood lineage commitment. Cell 121: 295-306.

Agata Y, Tamaki N, Sakamoto S, Ikawa T, Masuda K, Kawamoto H, Murre C. 2007. Regulation of T cell receptor $\beta$ gene rearrangements and allelic exclusion by the helix-loop-helix protein, E47. Immunity 27: 871-884.

Alonzo ES, Gottschalk RA, Das J, Egawa T, Hobbs RM, Pandolfi PP, Pereira P, Nichols KE, Koretzky GA, Jordan MS, et al. 2010. Development of promyelocytic zinc finger and ThPOK-expressing innate $\gamma \delta$ T cells is controlled by strength of TCR signaling and Id3. J Immunol 184: 1268-1279.

Bain G, Maandag ECR, Izon DJ, Amsen D, Kruisbeek AM, Weintraub BC, Krop I, Schlissel MS, Feeney A, van Roon $\mathrm{M}$, et al. 1994. E2A proteins are required for proper B cell development and initiation of immunoglobulin gene rearrangements. Cell 79: 885-892.

Bain G, Engel I, Robanus Maandag E, te Riele H, Voland J, Sharp L. 1997. E2A deficiency leads to abnormalities in $\alpha / \beta$ $\mathrm{T}$-cell development and to rapid development of T-cell lymphomas. Mol Cell Biol 17: 4782-4791. 
Barndt RJ, Dai M, Zhuang Y. 2000. Functions of E2A-HEB heterodimers in T-cell development revealed by a dominant negative mutation of HEB. Mol Cell Biol 20: 6677-6685.

Baù D, Sanyal A, Lajoie BR, Capriotti E, Byron M, Lawrence JB, Dekker J, Marti-Renom MA. 2011. The three-dimensional folding of the $\alpha$-globin gene domain reveals formation of chromatin globules. Nat Struct Mol Biol 18: 107-114.

Beck K, Peak MM, Ota T, Nemazee D, Murre C. 2009. Distinct roles for E12 and E47 in B cell specification and the sequential rearrangement of immunoglobulin light chain loci. J Exp Med 17: 2271-2284.

Bell JJ, Bhandoola A. 2008. The earliest thymic progenitors for T cells possess myeloid lineage potential. Nature 452: 764-767.

Bohn M, Heermann DW, van Driel R. 2007. Random loop model for long polymers. Phys Rev E 76: 051805.

Cecchini MG, Dominguez MG, Mocci S, Wetterwald A, Felix R, Fleisch H, Chisholm O, Hofstetter W, Pollard JW, Stanley ER, et al. 1994. Role of colony stimulating factor-1 in the establishment and regulation of tissue macrophages during postnatal development of the mouse. Development 120: $1357-1372$.

Cook PR. 1997. The transcriptional basis of chromosome pairing. J Cell Science 9: 1033-1040.

Decker T, Pasca di Magliano M, McManus S, Sun Q, Bonifer C, Tagoh H, Busslinger M. 2009. Stepwise activation of enhancer and promoter regions of the B cell commitment gene Pax5 in early lymphopoiesis. Immunity 30: 508-520.

Degner SC, Verma-Gaur J, Wong TP, Bossen C, Iverson GM, Torkamani A, Vettermann C, Lin YC, Ju Z, Schulz D, et al. 2011. CCCTC-binding factor (CTCF) and cohesin influence the genomic architecture of the Igh locus and antisense transcription in pro-B cells. Proc Natl Acad Sci 108: 9566-9571.

DeKoter RP, Singh H. 2000. Regulation of B lymphocyte and macrophage development by graded expression of PU.1. Science 288: 1439-1441.

Dixon JR, Selvaraj S, Yue F, Kim A, Li Y, Shen Y, Hu M, Liu JS, Ren B. 2012. Topological domains in mammalian genomes identified by analysis of chromatin interactions. Nature $\mathbf{4 8 5}$ : $376-380$.

Engel I, Johns C, Bain G, Rivera RR, Murre C. 2001. Early thymocyte development is regulated by modulation of E2A protein activity. J Exp Med 194: 733-746.

Ferreirós-Vidal I, Carroll T, Taylor B, Terry A, Liang Z, Bruno L, Dharmalingam G, Khadayate S, Cobb BS, Smale ST, et al. 2013. Genome-wide identification of Ikaros targets elucidates its contribution to mouse B-cell lineage specification and preB cell differentiation. Blood 121: 1769-1782.

Fullwood MJ, Liu MH, Pan YF, Liu J, Xu H, Mohamed YB, Orlov YL, Velkov S, Ho A, Mei PH, et al. 2009. An estrogenreceptor- $\alpha$-bound human chromatin interactome. Nature 462: $58-64$.

García-Ojeda ME, Klein Wolterink RG, Lemaître F, RichardLe Goff O, Hasan M, Hendriks RW, Cumano A, Di Santo JP. 2013. GATA-3 promotes T cell specification by repressing $\mathrm{B}$ cell potential in pro-T cells in mice. Blood 121: 17491759.

Ghisletti S, Barozzi I, Mietton F, Polletti S, De Santa F, Venturini E, Gregory L, Lonie L, Chew A, Wei CL, et al. 2010. Identification and characterization of enhancers controlling the inflammatory gene expression program in macrophages. Immunity 32: 317-328.

Guo C, Gerasimova T, Hao H, Ivanova I, Chakraborty T, Selimyan R, Oltz EM, Sen R. 2011a. Two forms of loops generate the chromatin conformation of the immunoglobulin heavy chain locus. Cell 147: 332-343.

Guo C, Yoon HS, Franklin A, Jain S, Ebert A, Cheng HL, Hansen E, Despo O, Bossen C, Vettermann C, et al. 2011b. CTCF-binding elements mediate control of V(D)J recombination. Nature 477: 424-430.

Heinz S, Benner C, Spann N, Bertolino E, Lin YC, Laslo P. 2010. Simple combinations of lineage-determining transcription factors prime cis-regulatory elements required for macrophage and B cell identities. Mol Cell 38: 576-589.
Iborra FJ, Pombo A, McManus J, Jackson DA, Cook PR. 1996. The topology of transcription by immobilized polymerases. Exp Cell Res 229: 167-173.

Ikawa T, Kawamoto H, Goldrath AW, Murre C. 2006. E proteins and Notch signaling cooperate to promote $\mathrm{T}$ cell lineage specification and commitment. J Exp Med 203: 1329-1342.

Ikawa T, Hirose S, Masuda K, Kakugawa K, Satoh R, ShibanoSatoh A. 2010. An essential developmental checkpoint for production of the T cell lineage. Science 329: 93-96.

Inlay MA, Bhattacharya D, Sahoo D, Serwold T, Seita J, Karsunky H, Plevritis SK, Dill DL, Weissman IL. 2009. Ly6d marks the earliest stage of B-cell specification and identifies the branchpoint between B-cell and T-cell development. Genes Dev 23: 2376-2381.

Jhunjhunwala S, van Zelm MC, Peak MM, Cutchin S, Riblet R, van Dongen JJM, Grosveld FG, Knoch TA, Murre C. 2008. The 3D structure of the immunoglobulin heavy-chain locus: Implications for long-range genomic interactions. Cell 133: $265-279$.

Jhunjhunwala S, van Zelm M, Peak M, Murre C. 2009. Chromatin architecture and the generation of antigen receptor diversity. Cell 138: 435-448.

Jones ME, Zhuang Y. 2012. Acquisition of a functional TCR during $\mathrm{T}$ lymphocyte development is enforced by HEB and E2A transcription factors. Immunity 6: 860-868.

Kind J, van Steensel B. 2010. Genome-nuclear lamina interactions and gene regulation. Curr Opin Cell Biol 22: 320-325.

Kondo M, Weissman IL, Akashi K. 1997. Identification of clonogenic common lymphoid progenitors in mouse bone marrow. Nat Immunol 91: 661-672.

Lai AY, Kondo M. 2006. Asymmetrical lymphoid and myeloid lineage commitment in multipotent hematopoietic progenitors. J Exp Med 203: 1867-1873.

Laslo P, Spooner CJ, Warmflash A, Lancki DW, Lee H-J, Sciammas R. 2006. Multilineage transcriptional priming and determination of alternate hematopoietic cell fates. Cell 126: $755-766$.

Lauritsen JP, Wong GW, Lee SY, Lefebvre JM, Ciofani M, Rhodes M, Kappes DJ, Zúñiga- Pflücker JC, Wiest DL. 2009. Marked induction of the helix-loop-helix protein $\mathrm{Id} 3$ promotes the $\gamma \delta \mathrm{T}$ cell fate and renders their functional maturation Notch independent. Immunity 31: 565-575.

Lee SY, Stadanlick J, Kappes DJ, Wiest DL. 2010. Towards a molecular understanding of the differential signals regulating $\alpha \beta / \gamma \delta$ T lineage choice. Semin Immunol 4: 237-246.

Li L, Leid M, Rothenberg EV. 2010a. An early T cell lineage commitment checkpoint dependent on the transcription factor Bcl11b. Science 329: 89-93.

Li P, Burke S, Wang J, Chen X, Ortiz M, Lee S-C. 2010 b. Reprogramming of $\mathrm{T}$ cells to natural killer-like cells upon Bcl11b deletion. Science 329: 85-89.

Li G, Ruan X, Auerbach RK, Sandhu KS, Zheng M, Wang P, Poh HM, Goh Y, Lim J, Zhang J. 2012. Extensive promotercentered chromatin interactions provide a topological basis for transcription regulation. Cell 148: 84-98.

Lieberman-Aiden E, van Berkum NL, Williams L, Imakaev M, Ragoczy T, Telling A, Amit I, Lajoie BR, Sabo PJ, Dorschner MO, et al. 2009. Comprehensive mapping of long-range interactions reveals folding principles of the human genome. Science 326: 289-293.

Lin HH, Grosschedl R. 1995. Failure of B-cell differentiation in mice lacking the transcription factor Ebf. Nature 376: $263-$ 267.

Lin YC, Jhunjhunwala S, Benner C, Heinz S, Welinder E, Mansson R, Chandra V, Dutkowski J, Ideker T, Glass CK, et al. 2010. A global network of transcription factors, involving E2A, EBF1 and FOXO1, that orchestrates B cell fate. Nat Immunol 11: 635-643.

Lin YC, Benner C, Mansson R, Heinz S, Miyazaki K, Miyazaki M, Chandra V, Bossen C, Glass CK, Murre C. 2012. Global changes in nuclear positioning of genes and intra- and interdomain genomic interactions that orchestrate B cell fate. Nat Immunol 12: 1196-1204. 
Livak F, Tourigny M, Schatz DG, Petrie HT. 1999. Characterization of TCR gene rearrangements during adult murine T cell development. $J$ Immunol 162: 2575-2580.

Lucas JL, Bossen C, Murre C. 2011. Transcription and recombination factories: Common features? Curr Opin Cell Biol 2: 318-324.

Mansson R, Zandi S, Welinder E, Tsapogas P, Sakaguchi N, Bryder D, Sigvardsson M. 2010. Single-cell analysis of the common lymphoid progenitor compartment reveals functional and molecular heterogeneity. Blood 115: 2601-2609.

Mansson R, Welinder E, Ashber J, Lin YC, Benner C, Glass CK, Sigvardsson M, Murre C. 2012. Positive intergenic feedback circuitry, involving EBF1 and FOXO1, orchestrates B-cell fate. Proc Natl Acad Sci 108: 17402-17407.

Medina KL, Pongubala JMR, Reddy KL, Lancki DW, DeKoter R, Kieslinger M. 2004. Assembling a gene regulatory network for specification of the B cell fate. Dev Cell 7: 607-617.

Miyazaki M, Rivera RR, Miyazaki K, Lin YC, Agata Y, Murre C. 2011. The opposing roles of the transcription factor E2A and its antagonist Id 3 that orchestrate and enforce the naïve fate of T cells. Nat Immunol 12: 992-1001.

Münkel C, Eils R, Dietzel S, Zink D, Mehring C, Wedemann G, Cremer T, Langowski J. 1999. Compartmentalization of interphase chromosomes observed in simulation and experiment. J Mol Biol 285: 1053-1065.

Murre C. 2005. Helix-loop-helix proteins and lymphocyte development. Nat Immunol 6: 1079-1086.

Murre C. 2009. Developmental trajectories in early hematopoiesis. Genes Dev 23: 2366-2370.

Nutt SL, Heavey B, Rolink AG, Busslinger M. 1999. Commitment to the B-lymphoid lineage depends on the transcription factor Pax5. Nature 401: 556-562.

Paulson JR, Laemmli UK. 1977. The structure of histone-depleted metaphase chromosomes. Cell 12: 817-828.

Pronk CJH, Rossi DJ, Månsson R, Attema JL, Norddahl GL, Chan CKF, Sigvardsson M, Weissman IL, Bryder D. 2007. Elucidation of the phenotypic, functional, and molecular topography of a myeloerythroid progenitor cell hierarchy. Cell Stem Cell 1: 428-442.

Revilla-I-Domingo R, Bilic I, Vilagos B, Tagoh H, Ebert A, Tamir IM, Smeenk L, Trupke J, Sommer A, Jaritz M, et al. 2012. The B-cell identity factor Pax 5 regulates distinct transcriptional programs in early and late B lymphopoiesis. EMBO J 31: 3130-3146.

Sachs RK, van den Engh G, Trask B, Yokota H, Hearst JE. 1995. A random-walk/giant-loop model for interphase chromosomes. Proc Nat Acad Sci 92: 2710-2714.

Schmitt TM, Zúñiga-Pflücker JC. 2002. Induction of T cell development from hematopoietic progenitor cells by $\delta$-like1 in vitro. Immunity 17: 749-756.
Sedat J, Manuelidis L. 1978. A direct approach to the structure of eukaryotic chromosomes. Cold Spring Harb Symp Quant Biol 42: $331-350$.

Sexton T, Yaffe E, Kenigsberg E, Bantignies F, Leblanc B, Hoichman M, Parrinello H, Tanay A, Cavalli G. 2012. Three-dimensional folding and functional organization principles of the Drosophila genome. Cell 148: 458-472.

Spangrude G, Heimfeld S, Weissman I. 1998. Purification and characterization of mouse hematopoietic stem cells. Science 241: 58-62.

Taghon T, Rothenberg E. 2008. Molecular mechanisms that control mouse and human T cell development. Semin Immunopathol 30: 383-398.

Taghon T, Yui MA, Pant R, Diamond RA, Rothenberg EV. 2006. Developmental and molecular characterization of emerging $\beta$ - and $\gamma / \delta$-selected pre-T cells in the adult mouse thymus. Immunity 24: 53-64.

Ting CN, Olson MC, Barton KP, Leiden JM. 1996. Transcription factor GATA-3 is required for development of the T-cell lineage. Nature 384: 474-478.

Treiber T, Mandel EM, Pott S, Györy I, Firner S, Liu ET, Grosschedl R. 2010. Early B cell factor 1 regulates B cell gene networks by activation, repression, and transcription- independent poising of chromatin. Immunity 32: 714-725.

Ueda-Hayakawa I, Mahlios J, Zhuang Y. 2009. Id3 restricts the developmental potential of $\gamma \delta$ lineage during thymopoiesis. $J$ Immunol 182: 5306-5316.

Verykokakis M, Boos MD, Bendelac A, Adams EJ, Pereira P, Kee BL. 2010. Inhibitor of DNA binding 3 limits development of murine slam-associated adaptor protein-dependent "innate" $\gamma \delta$ T cells. PLoS One 15: e9303.

Wada H, Masuda K, Satoh R, Kakugawa K, Ikawa T, Katsura Y. 2008. Adult T-cell progenitors retain myeloid potential. $\mathrm{Na}$ ture 452: 768-772.

Weber BN, Chi AW, Chavez A, Yashiro-Ohtani Y, Yang Q, Shestova O, Bhandoola A. 2011. A critical role for TCF-1 in T-lineage specification and differentiation. Nature 476: 63-68.

Weissman IL. 2000. Stem cells: Units of development, units of regeneration, and units in evolution. Cell 100: 157-168.

Yashiro-Ohtani Y, He Y, Ohtani T, Jones ME, Shestova O, Xu L, Fang TC, Chiang MY, Intlekofer AM, Blacklow SC, et al. 2009. Pre-TCR signaling inactivates Notch1 transcription by antagonizing E2A. Genes Dev 23: 1665-1676.

Yui MA, Feng N, Rothenberg EV. 2010. Fine-scale staging of T cell lineage commitment in adult mouse thymus. J Immunol 185: $284-293$.

Zhuang Y, Soriano P, Weintraub H. 1994. The helix-loophelix gene E2A is required for B cell formation. Cell 79: $875-884$. 


\section{$\$_{\text {CSH }}^{\infty}$ Cold Spring Harbor Symposia SYMPOSIA On Quantitative Biology}

\section{The Epigenetics of Early Lymphocyte Development}

C. Murre

Cold Spring Harb Symp Quant Biol 2013 78: 43-49 originally published online October 3, 2013 Access the most recent version at doi:10.1101/sqb.2013.78.020149

References This article cites 74 articles, 25 of which can be accessed free at: http://symposium.cshlp.org/content/78/43.full.html\#ref-list-1

\section{License}

Email Alerting Receive free email alerts when new articles cite this article - sign up in Service the box at the top right corner of the article or click here. 